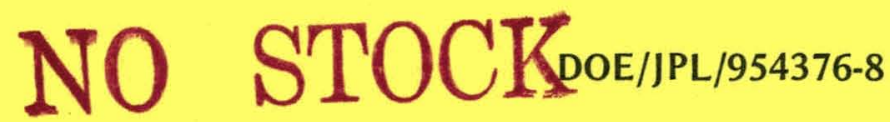

LASER-ZONE GROWTH IN A RIBBON-TO-RIBBON (RTR) PROCESS

SILICON SHEET GROWTH DEVELOPMENT FOR THE LARGE AREA

SILICON SHEET TASK OF THE LOW COST SOLAR ARRAY PROJECT

Technical Quarterly Report No. 9, Motorola Report No. 2256/12

October 1-December 31, 1978

By
A. Baghdadi
R. W. Gurtler
R. Legge
B. Sopori
M. J. Rice
R. J. Ellis

Work Performed Under Contract No. NAS-7-100-954376

Motorola Inc.

Semiconductor Group

Phoenix, Arizona

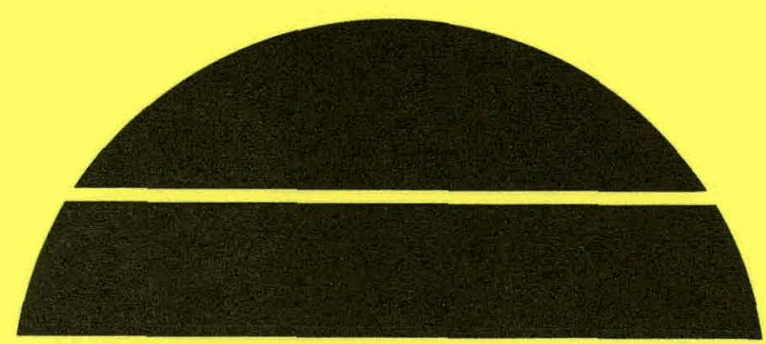

\section{U.S. Department of Energy}




\section{DISCLAIMER}

This report was prepared as an account of work sponsored by an agency of the United States Government. Neither the United States Government nor any agency Thereof, nor any of their employees, makes any warranty, express or implied, or assumes any legal liability or responsibility for the accuracy, completeness, or usefulness of any information, apparatus, product, or process disclosed, or represents that its use would not infringe privately owned rights. Reference herein to any specific commercial product, process, or service by trade name, trademark, manufacturer, or otherwise does not necessarily constitute or imply its endorsement, recommendation, or favoring by the United States Government or any agency thereof. The views and opinions of authors expressed herein do not necessarily state or reflect those of the United States Government or any agency thereof. 


\section{DISCLAIMER}

Portions of this document may be illegible in electronic image products. Images are produced from the best available original document. 


\section{NOTICE}

This report was prepared as an account of work sponsored by the United States Government. Neither the United States nor the United States Department of Energy, nor any of their employees, nor any of their contractors, subcontractors, or their employees, makes any warranty, express or implied, or assumes any legal liability or responsibility for the acsurary, completeness nt usefulness of any information, apparatus, product or process disclosed, or represents that its use would not infringe privately owned rights.

This report has been reproduced directly from the best available copy.

Available from the National Technical Information Service, U. S. Department of Commerce, Springfield, Virginia 22161.

Price: Paper Copy $\$ 1.50$

Microfiche $\$ 3.00$ 


\title{
LASER-ZONE GROWTH IN A RIBBON-TO-RIBBON (RTR) PROCESS \\ SILICON SHEET GROWTH DEVELOPMENT FOR THE LARGE AREA \\ SILICON SHEET TASK OF THE LOW COST SOLAR ARRAY PROJECT
}

TECHNICAL QUARTERLY REPORT NO. 9

MOTOROLA REPORT NO. $2256 / 12$

1 OCtober 1978 - 31 December 1978

JPL CONTRACT NO. 954376

BY

A. BAGHDADI, R.W. GURTLER, R. LEGGE, B. SOPORI, M.J. RICE, R.J. ELLIS

THE JPL LOW-COST SOLAR ARRAY PROJECT IS SPONSORED BY THE U.S. DEPARTMENT OF ENERGY AND FORMS PART OF THE SOLAR PHOTOVOLTAIC CONVERSION PROGRAM TO INITIATE A MAJOR EFFORT TOWARD THE DEVELOPMENT OF LOW-COST SOLAR ARRAYS. THIS WORK WAS PERFORMED FOR THE JET PROPULSION LABORATORY, CALIFORNIA INSTITUTE OF TECHNOLOGY BY AGREEMENT BETWEEN NASA AND DOE.

This report was prepared as an account of work United States Uor United States Govemment. Neither the Energy, nor any of United States Department of contractors, subcontractors, or thes, nor any of their any wartanty, express or implied employees, makes or usy or responsibility for the ecer asumes any legal or usefulness of any information, appacy, completeness process disclosed, or represents that its use would or
infringe privately owned infringe privately owned rights.

\section{PREPARED BY} \\ MOTOROLA INC. SEMICONDUCTOR GROUP \\ 5005 EAST McDOWELL ROAD \\ PHOENIX, ARIZONA 85008
}




\section{TABLE OF CONTENTS}

SECTION

1.0

2.0

3.0

4.0

5. 0

6.0

7.0

8.0

9.0
TITLE

Semicontinuous Folycrystalline Ribbon Development

Ribbon Contamination

Furnace Design

Gettering Studies - Cz Feedstóck

Sölàr lèlls - LVU reedstock

Economic Analysis: Update

Plans

Problems

New Technology
PACSE

1

5

9

12

14

16

20

21

22 


\section{SUMMARY}

We have achieved breakthroughs in two areas critical to the RTR process. A series of flat polycrystalline ribbons measuring $5 \mathrm{~cm} \times 61 \mathrm{~cm}$ was grown and successfully separated from 24" long Mo substrates. Our first solar cells on gettered RTR silicon were grown from pre-etched ( $21 / 2 \mathrm{mil}$ ) CVD feedstock. The best cell had a conversion efflciency of $10.6 \%$, with $v_{x:}=0.565$ volts. $I_{s c}=29.8 \mathrm{ma} / \mathrm{cm}^{2}$, and a fill factor of $63 \%$. The low fill factor does indicate that still higher efficiencies can be attained on this material by improving the processing sequence.

The economic analysis for the overall RTR process has been updated in response to our technological progress. The total price for the overall process, including feedstock, was projected at $\$ 19-\$ 23 / \mathrm{m}^{2}$, assuming multiple ribbon growth.

\footnotetext{
* This efficiency occurred on a current run during the month of January and is reported hore to show the most recent accomplishment.
} 
Development of the semicontinuous polysilicon ribbon reactor continued. It was found necessary to increase the spacing between the fiberglass curtains at the exit and to increase the inert gas flow for the curtains to prevent backstreaming of air into the furnace. Several runs were made varvincy temperature profiles, process gas flow, and belt speed. It was found nocossary to maintain the reaction zone at $1150^{\circ} \mathrm{C}$ for shearing of the ribbon from the substrate to reliably take place (as was predicted from results in a static induction heated reactor).

Flat ribbons $5 \mathrm{~cm} \times 61 \mathrm{~cm}$ long were deposited on $0.040^{\prime \prime} \times 2 " 1 \times 24^{\prime \prime} \mathrm{MO}$ substrates carried through the furnace on a $0.015^{\prime \prime}$ thick Mo belt (Figure 1). Deposition directly on a thin Mo belt had resulted in "crowned" or curved ribbons which would not fit in the RTR apparatus, hence the use of thicker substrates on top of the belt. New belts $0.020^{\prime \prime}$ thick have been received, and initial experiments indicate that the silicon ribbon deposited on this thickness substrate/belt crowne very little and would be sultathle for pile growth. Belts $0.020^{\prime \prime}$ thick cannot bo used on the proesent rystem eince thes feed and takeup reels are too small in diameter and the belt would break after a heat treatment. Design of a new system, with large diameter reels and utilizing four Mo belts to completely cover the four sides of the reactor chamber, is underway.

\subsection{SUBSTRATE STUDIES}

Although $\mathrm{Si}_{3} \mathrm{~N}_{4}$ coatings on the Mo substrates proved to be ineffective as a diffusion barrier, they have proved to be beneficial in promoting smonth, uniform silicide formation which is essential to obtain successful shearime. 

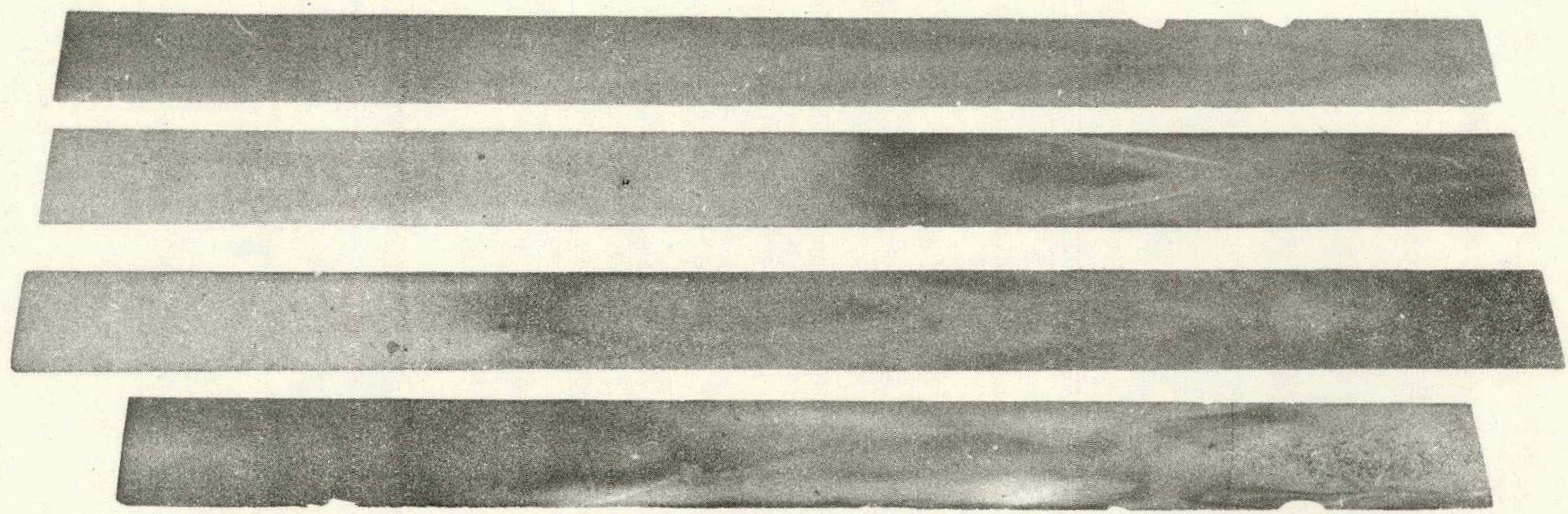

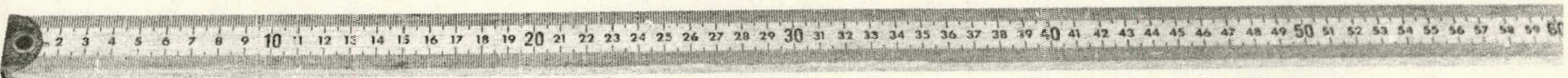

=igure 1: SILICON FIEBONS GROWN IN SEMICONTINUOUS BEL- FJRNACE 
;io, coatings appear to be effective barriers. Metallographic sections show no, ,ilicide formation (Figure 2 ) and the silicon films are stronoly adherent and do not shear off.

Experiments were made using 304 stainless steel $(18.5 \% \mathrm{Cr}, 9.5 \% \mathrm{Ni}$, $0.08 \% \mathrm{C}$ max, balance $\mathrm{Fe}$ ) and 410 stainless steel ( $12 \% \mathrm{Cr}, 0.15 \% \mathrm{C}$ max, balance $\mathrm{Fe}$ ) as substrates at temperatures of $950^{\circ} \mathrm{C}$ and $1050^{\circ} \mathrm{C}$, respectively. The films visually appeared not to be silicon and were strongly adherent in spite of much higher expansion coefficients of the substrates. It is known that $\mathrm{Fe}$ and $\mathrm{Ni}$ form silicides at low temperatures and it may be conjectured that they diffuse as rapidly above $900^{\circ} \mathrm{C}$ and that the films consist entirely of silicide. They are presently being analyzed. 


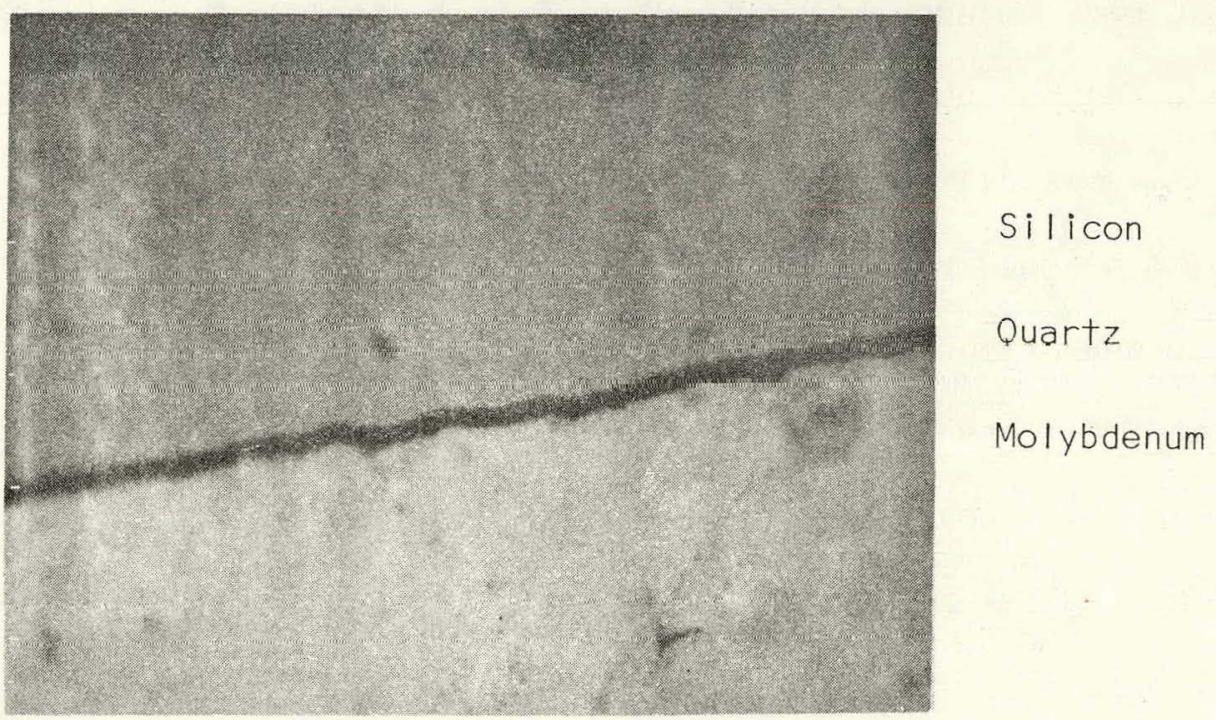

FIGURE 2: SILICON-QUARTZ-MOLYBDENUM INTERFACE 
Precently, solar celle; fabricated on RTR ribbons have exhibited low efficiencies. Because of suspected Mo contamination, these results were rot considered surprising in the case of CVD substrates. However, we have also observed low efficiencies for ribbons grown from single crystal fejerstock, which is contrary to earller results. In attempting to determine the cause of the abnormally low cell efficiencies, it was found that diffusion lengths on as-grown ribbons had dropped to very low values. While typical diffusion lengths for as-grown single crystal feedstock have previously been reported. in the $5 \mu \mathrm{m}$ to $10 \mu \mathrm{m}$ range, recent measurements on ribbons grown from both CVD and single crystal feedstock showed diffusion lengths that were essentially inco. Fven in finlshed solar cells which have undergone a process sequence which was garller rhown to produces conslderable: "rolterlng," dlffuelon lengthe" have been usually much lower than expected. This is in contrast to prevlour. results which have shown average diffusion lengths in excess of $50 \mathrm{um}$.

This is obviously a serious problem and major efforts were initiated to isolate the difficulty. We have studied our records and it appears that the drop in diffusion length coincided with changes made in post-heaters and the incorporation of a pre-hoater. These changes were made to allow growth of wider ribbons and to improve the thermal profile sufficiently to handle CVD ribbons. Close scrutiny of the present furnaces has brought to light several possible problems.

1) Possible platinum contamination. Platinum heater elements are being used and, because of the particular geometries involved, platinum could be transported to the melt by means of gaseous diffusion. This possibility was much less likely in the previous furnace design. Heutron Activation Analysis (NAA) has been performed on several samples. Samples which had not been passed through the furnace exhibited Pt levels below about 70 ppbw (the detection 
limit. However, one sample which has been regrown with our present furnace was shown to have 1.2 ppma of Pt, a clear case of contamination.

2) Vaporization of furnace parts. Because of the high reflectivity of liquid silicon to the $\mathrm{CO}_{2}$ laser beam, a great deal of power is contained in the reflected beam. This beam may strike parts of the furnace, which can then vaporize. These contaminants can be transported to unmelted and melted regions of the ribbon, again by diffusion and convection processes. Materials of concern are quartz, stainless steel, high-alumina insulation, and ceramic parts, all of which can have teace metallic impurities.

3) Long-distance convective transport of contaminants. The present growth chamber is quite large with numerous mechanical, optical and electronic components within the enclosure. Whlle these part's are normally cool, stray laser beams could cause emission of volatile components. An example would be the plastic shields used in front of the TV cameras. Furthermore, normal convective air currents could bring general contaminants to the melt.

\section{$2.1 \quad$ EXPERIMENTS}

In an attempt to clarify the nature of the problem, several cxperiments were performed, all with single-crystal feedstock. First, in an effort to duplicate earller runs whlch had resulled in good material, the original small furnace was set up. Numerous growth runs were made but all resulted in unmeasurably short diffusion lengths. Next, growth runs were mide withiout any furnace at all. To perform these experiments, very small growth rates $(\sim 0.2 " 1 \mathrm{~min})$ were necessary, and a combination of focused and defocused beams was used to produce some stress rellet in the ribbull. Again, "zero" diffusion lengths resulted, indicating that general contamination was prevalent. During these experiments, various feedstock sources (sawn ingots, scrited wafers, Czochralski, float-zone, etc.) and various pre-cleaning/etching steps were 
utilized in an attempt to eliminate possible contamination from the material itself, or from pre-cleaning residues.

In order to verify that a pervasive atmospheric contaminant is indeed to blame, a special chamber was constructed. This chamber, illustrated in Figure 3, utilized a copper tube with narrow slots cut into the top and bottom for ribbon transport, and slots in the sides for laser beam access and vlewing. Pure nitrogen (and othor gas ambient:s) entered at the ends of the tube, exiting at the slots. Copper was used because of its high reflectivity at 10.6 um (to avoid vaporization of the tube) and because copper is not a serlous lifetime killer when present in sllicon. The interior surface of the copper was roughened so that radiation reflected from the silicon onto the walls of the tube would be diffusely reflected back onto the sample, i.e. it would not act like a cylindrical reflector. (l.t is interesting to note the similarity of this configuration with the hemispherical reflector concept. In fact, one experiment with smooth inner walls did show a significantly increased coupling. Infortunately, it also resulted in an unstable molten zone, so we had to sand-t,last the inner walls of the coppor tube to reduce thi c; effext.)

This experiment was successful, and diffusion lengths of fo um to $1 \%$ um were obtained on ribbons grown in the copper tube. Since this experimental arrangement was primarily a protectlve cover against the atmosphere in the growth chamber, it confirmed the existence of a pervasive atmospheric contaminant. We then disassembled the growth chamber and cleaned it thoroughly, removing all unprotected plastic surfaces (and covering those that could not. be removed with aluminum foil). The first sample regrown from $\mathrm{Cz}$ feedstock in the clean growth chamber had an SPV-measured diffusion length of $18 \mu \mathrm{m}$. In parallel with our efforts to clean up the growth chamber, we carried out some jettering sxperiments. These experiments were spectacularly succes: ful, and are fully discussed in sections 4.0 and 4.1 . 


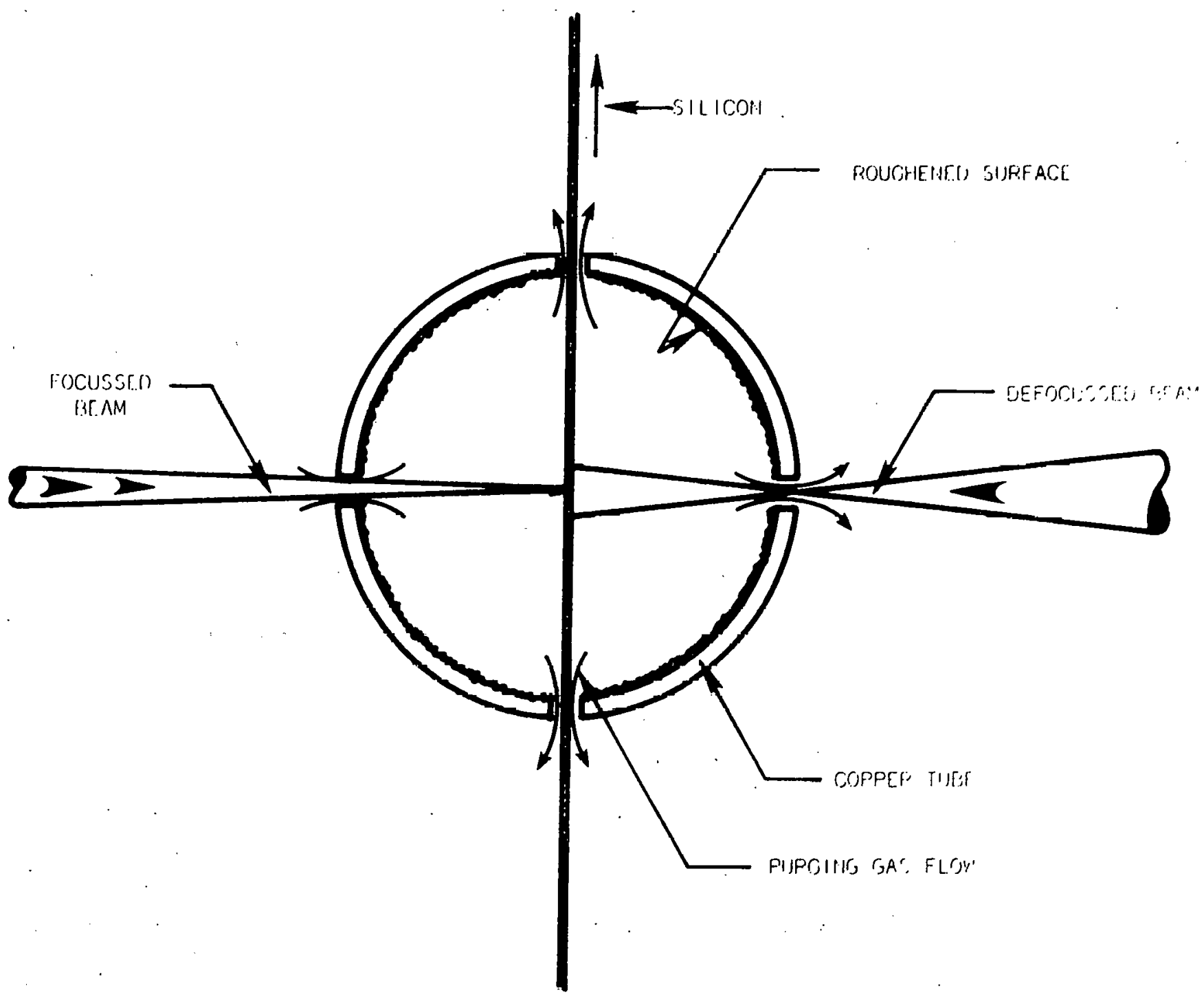

FIGURE 3. CONTROLLED ATMOSPHERE EXPERIMENT 
Furnace designs to date have catered primarily to achievement of wide ribbon growth at high velocities. Because of this emphasis, possible contamination mechanisms have not recelved the attention they warrant. Recent NAA analyses have shown that, at least occasionally, platinum is making its way into the grown ribbons; this platinum is coming from the platinum heater elements. An additional problem is caused by reflection of the laser beam onto furnace parts that can vaporize. These mechanisms are shown in Figure 4 , which also illustrates the type of structure now in use.

To alleviate these problems, an alternative furnace configuration is being investigated. This modified structure is conceptually indicated in Figure 5. Purging gas is introduced at the top and bottom of the furnace, exiting at the central region where the melt occurs. By adjusting each of the heater elements, the proper temperature profile may be achieved (with the gas flow). By proper choice of flow rates, the exit gas velocity should effectively reduce the possibility of contaminant counter-diffusion. Platinum shields protect the quartz and other components of the furnace from the reflected beam. Since the platinum shields are at a relatively low temperature $(212000 \mathrm{C})$ and are bathed by the purging gas stream, no contamination problems wore anticipated. 


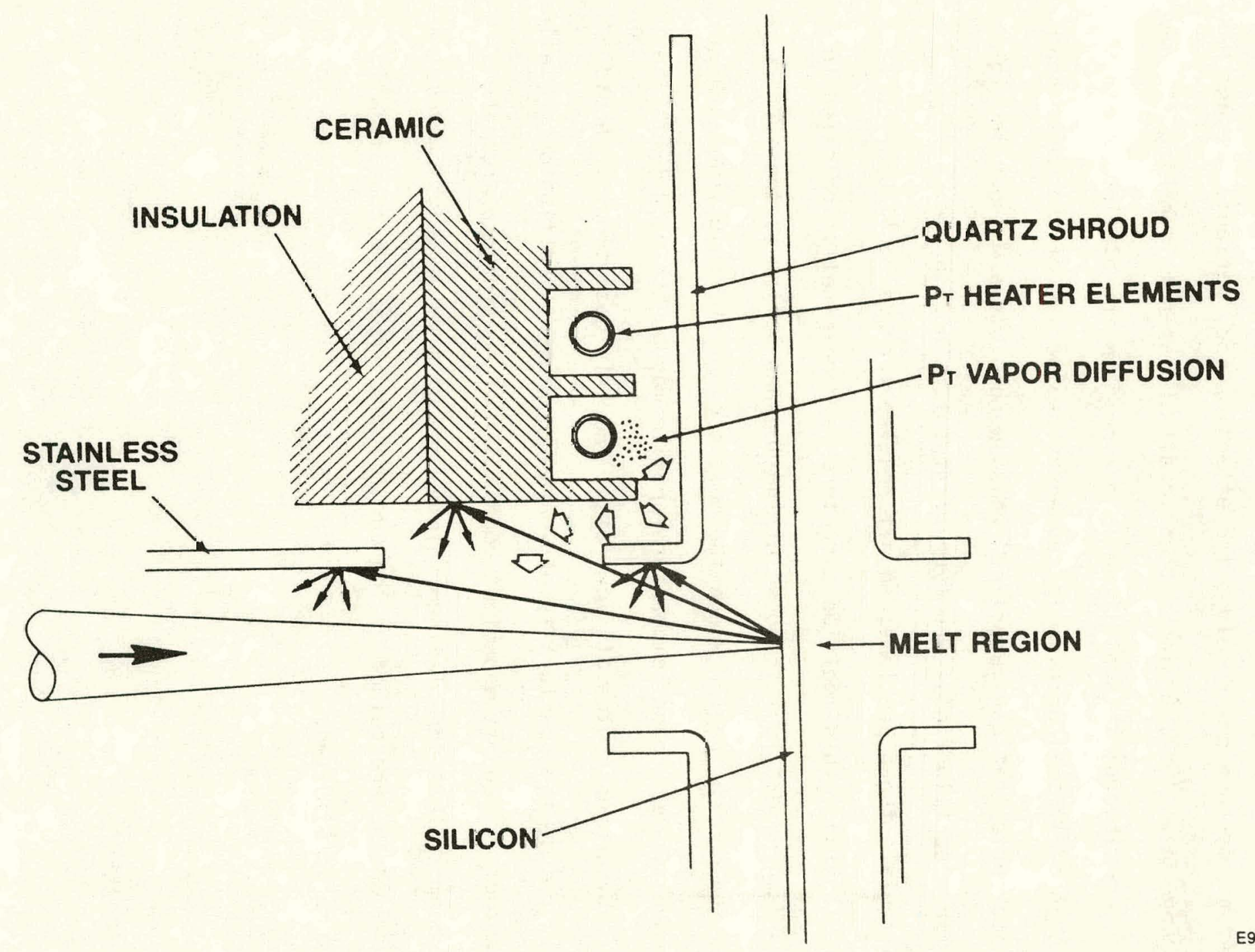

FICLRE 4: COSSIIZLE. S.URCES OF CONTAMINATION IN FURNACE 


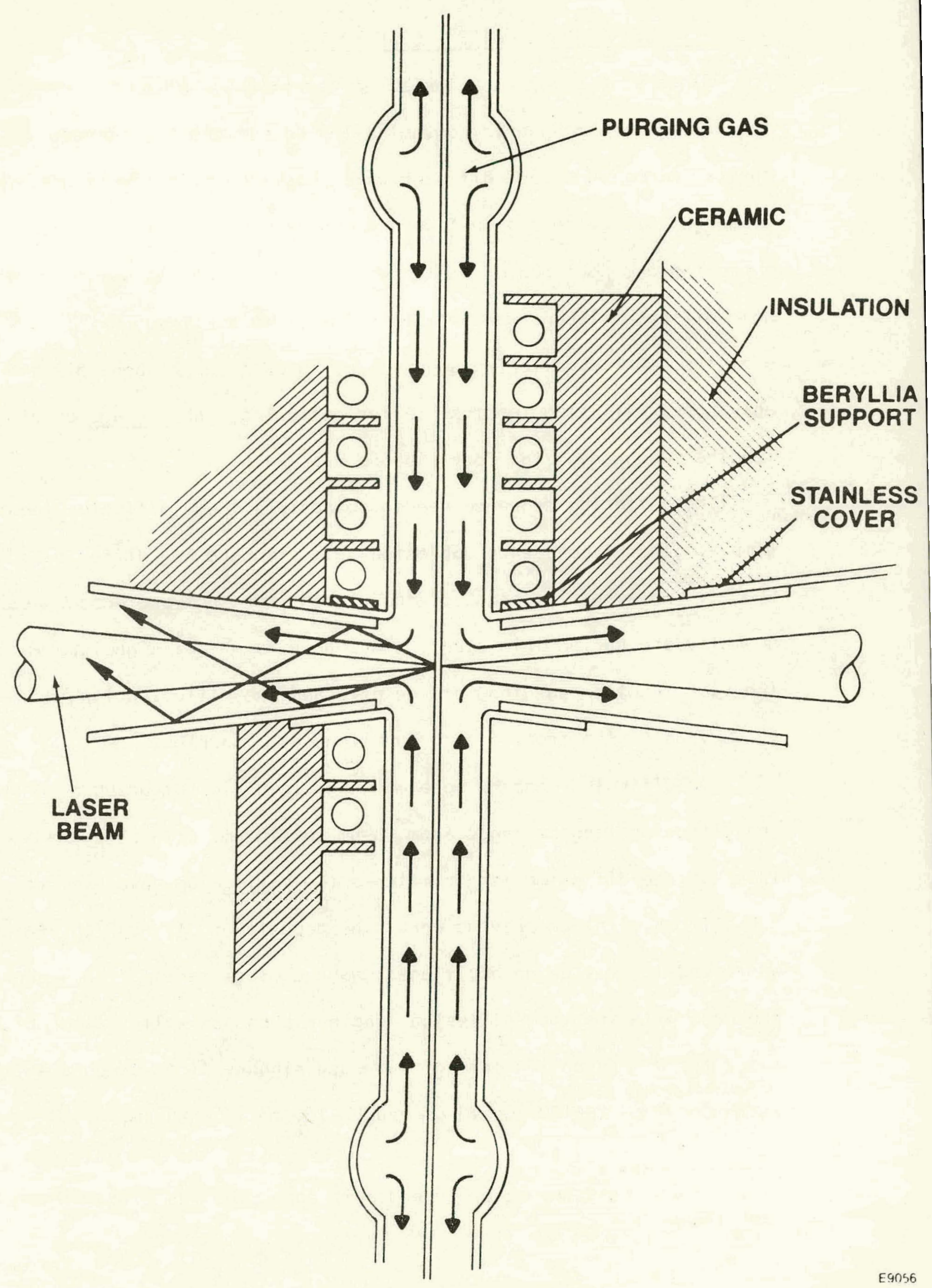

FIOURE 5: MUREED FURNACE DESICN 
Since we did not know the actual element (or elements) responsible for the pervasive atmospheric contamination in our growth chamber, we speculated that it might be a fast diffuser which could be effectively gettered. A number of $5 / 8$ " wide ribbons* were grown from $\mathrm{Cz}$ feedstock without using a pre-heater, post-heater or the copper tube. The diffusion lengthes in some of these ribbons were measured immediately after growth; four ribton; went through the gettering sequence. The as-grown ribbons all had unmeasurably short dittusion lengths. Alter gcttoring, the average of eiqht diffusion lengths measured on the four ribbons was $124 \mu \mathrm{m}$.

The gettering sequence needed to achieve these diffusion lengths is very simple. The ribbons were subjected to a standard $\mathrm{PH}_{3}$ diffusion process at $900^{\circ} \mathrm{C}$. However, the backs of the ribbons were not protected (as they normally are during this step). Thus an $\mathrm{n}^{+}-p-\mathrm{n}^{+}$structure was formed. The bar:k junction was ther etched of $f$, and the dlffuslon lengths measured by OCPV using the front $n^{+}-p$ junctions as a barrior.

Two diffusion lengths were measured in different areas of nach ribusin. The diffusion lengths range from $88 \mu \mathrm{m}$ to $210 \mu \mathrm{m}$, with an average of $124 \mu \mathrm{m}$. This average diffusion length matches the maximum we have ever reported on RTR silicon. In our previus work, the deposition of the $\mathrm{Si}_{3} \mathrm{~N}_{4} \mathrm{AR}$ coating was found to provide an additional measure of gettering. This seems to be the case with the long diffusion length ribbons as well. Arler $\mathrm{Si}_{3} \mathrm{~N}_{4}$ doposition, the diffusion lengths for two such ribbons (from Czochralski feedstock) increased from 88-120 to $275 \mu \mathrm{m}$ and $80-130$ to $130-328 \mu \mathrm{m}$.

* This growth was done before the growth apparatus was disassembled and cleaned. 
1.1 BITIPINC TIIUHFS - CVD FEEDSTOCK

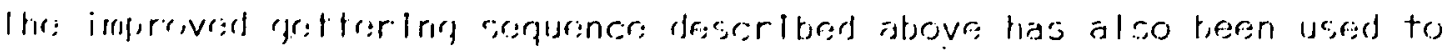

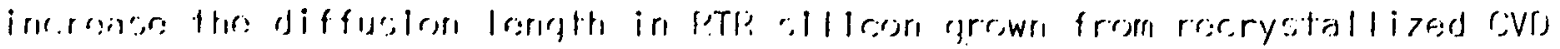
polyribbon.

Diffusion lengths from 25-50 um have been obtained after. the two-rided $\mathrm{PH}_{3}$ diffusion. The average value for 14 CVD ribbons is $24 \mu m$, with orie sample as high as $130 \mu \mathrm{m}$. The $\mathrm{Si}_{3} \mathrm{~N}_{4}$ deposition can result in a further increase in diffusion length, although the results are less spectacular and the data more scattered than in the case of Czochralski feedstock. These results represent an increase by more than an order of magnitude over diffusion lengths previously reported for this material.

Experiments are also being done to further improve the gettering. One promising approach is to do the normal two-sided $\mathrm{PH}_{3}$ diffusion, strip both sides of $\approx 10$ um of $\mathrm{jillcon}$, which removes the $\sim 0.5 \mathrm{um}$ deep junction, arid then process the ribbon as usual. The first attempt resulted in a Civo ribtorn with a diffusion length as high as $190 \mu \mathrm{m}$ before $\mathrm{Si}_{3} \mathrm{~N}_{4}$ deposition.

Three major changes in our experimental procedures are responsible for. this improvement:

1. All our CVD feedstock is now etched prior to laser recrystallization. Roughly $1 / 2 \mathrm{mil}$ of $\mathrm{Si}$ is removed from each side of the ribbon.

2. These ribbons were grown without a pre- or post-heater. Previous ribbons grown with the hoatcrs might liave been contaminated by platinum and other vaporized furnace componerils.

3. Two-sided phosphorus diffusion is now used to getter the silicon ribbon. Experiments to further optimize the gettering sequence are underway. 
The first solar cells have been fabricated on the gettered CVD material. The best overall efficiency was $10.6 \%$, * with $v_{o c}=0.565,1_{\text {sc }}=29.8 \mathrm{ma} / \mathrm{cm}^{2}$ and a 63\% fill factor for simulated AM1 illumination (see Figure 6). The diffusion length was measured after complete cell fabrication to range from 27 to $40 \mu \mathrm{m}$. Note that the voltage is the highest we have ever attained; on single crystal foedstuck RTR ribbon, $V_{o c} \sim 0.50$. The short clrcuit current is also very encouraging. The low fill factor shows that we have room for improvement. For example, will a 76\% fill factor (which has been observed on CVD RTR samples), the efficiency would increase to $12.8 \%$.

The metallization used for this cell used an experimental electroplated $\mathrm{Ni}$-Ag contact, which may be responsible for the poor fill factor. A short, 5-minute sinter at $\sim 300^{\circ} \mathrm{C}$ was used. The open circuit voltage diu hut degrodo during metallization.

\footnotetext{
* These numbers wore updated in proof-- the best cell was completed in January
} 1979 and included in this report to show the most recent accomplishment. 


$\begin{array}{ll}\text { CELL ND.: } & 967 \mathrm{~A}-2 \\ \text { AREA: } & 1.32 \mathrm{~cm}^{2} \\ V_{\text {OC }}: & 0.565 \mathrm{VOLTS} \\ \text { I }_{\text {SC }}: & 29.8 \mathrm{MA} / \mathrm{CM}^{2}\end{array}$

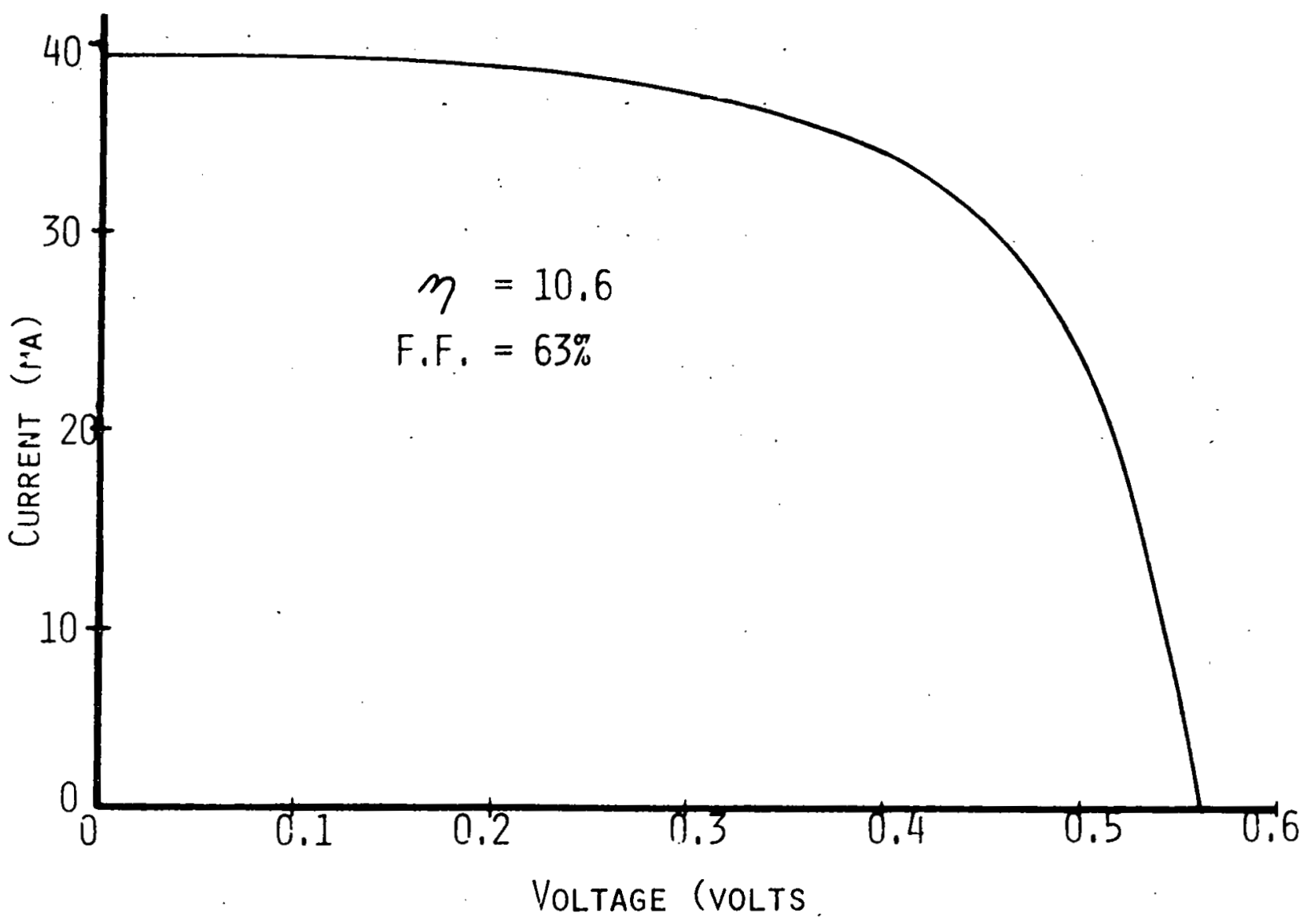

FISURE 6. I-V CATA ON RTR SAMPLE GROWN FROM CVD FEEDSTOCK 


\subsection{ECONOMIC ANALYSIS: UPDATE}

In our most recent price projection (1), we reported a $\$ 16.9 / \mathrm{m}^{2}$ price for polycrystalline ribbon grown by CVD and an RTR add-on price ranging from approximately $\$ 20 / \mathrm{m}^{2}$ at $100 \mathrm{~cm}^{2} / \mathrm{min}$ to $\$ 11 / \mathrm{m}^{2}$ at $200 \mathrm{~cm}^{2} / \mathrm{min}$ (multiple ribbons). These results are being updated in response to changes in three factors with significant cost impact:

1. Deposition Ceometry: This is the most important factor. We had assumed a two-belt deposition system, malnly because $1+$ appeared that a two-belt system would bo simpler to design than a four-bell system. Recent experiments with silicon ribbon deposition systems (2), however, have shown that a four-wall system, since it eliminates the need for masking, would not be a particularly difficult design problem.

2. Capital Cost-Laser: The cost of a multi-ki lowatt $\mathrm{CO}_{2}$ laser was $\$ 30 /$ watt in 1977. However, the production of high-power $\mathrm{CW} \mathrm{CO}_{2}$ lasers sultable for heat-treating, surface hardening, etc., apppllcations is predicted to increase by $25 \%$ per yoar through 1985 (3), Thus the total production of these lasers will more than triple over the next five years. Assuming a $20 \%$ learning curve, the cost of high-power $\mathrm{CO}_{2}$ lasers could drop to $\$ 21 /$ watt by 1984 (in constant dollars). This price was used for this analysis.

3. Quartz Furnace Liner: Since the four-belt system protects the quartz from being attacked by $\mathrm{SiHCl}_{3}, \mathrm{HCl}$ and $\mathrm{B}_{2} \mathrm{H}_{6}$, the quartz furnace liner wlll need to be replaced only on a yearly basis.

The SAMICS equation was used to calculate the price of riubons: SAMICS = $0.49(E Q P T)+96.9($ SOFT) $+2.1(L A B O R)+1.3($ UTILITY) + 1.3 (MATERIAL). AII results are expressed in 1975 dollars. As requested by JPL, the cost of the 
source gas was not burdened. The deposited rlbbon thickness was $220 \mu \mathrm{m}$. Twerity microns are then etched off the back surface to remove the Mo contamination. The ribben is then stretched to a 100 um thickness during the RTP recrystallization. The price of the polyribbon is axprosesed $1 \mathrm{n} \mathrm{q} / \mathrm{m}^{2}$ of recrystallized rlbbon.

The results of these calculations are shown in Tables 1 and 11 . Table 1 shows the price dependence for the polyribbon on deposition rate, molybdenum belt thickness and Mo belt cycles. Choosing a fairly modest set of parameters- -100 cycles/belt, $600 \mu \mathrm{m}$ deposition rate--the polyribbon can be grown for $\$ 12.6 / \mathrm{m}^{2}$. Table 11 shows the add-on price for the RTR recrystallization, as well as the total price assuming $\$ 12.6 / \mathrm{m}^{2}$ polyribbon: 
TABLE 1

POL,YCRYSTALLINE SILICON RIBBON BY CVD

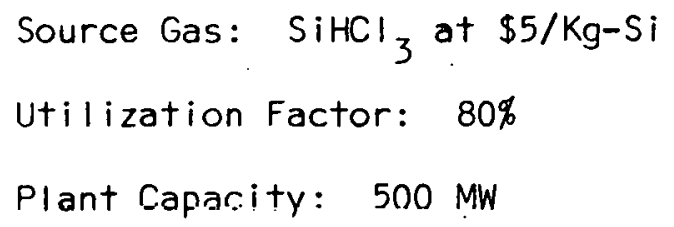

\begin{tabular}{|c|c|c|c|c|c|}
\hline $\begin{array}{l}\text { Mo Belt } \\
\text { Utilization } \\
\text { (cycles). }\end{array}$ & $\begin{array}{l}\text { Mo Belt } \\
\text { Thickness } \\
(\mu \mathrm{m})\end{array}$ & $\begin{array}{l}\text { Silicon } \\
\text { Deposition } \\
\text { efficiency } \\
\text { (per pass) }\end{array}$ & $\begin{array}{l}\text { Deposition } \\
\text { Rate } \\
(\mu \mathrm{m} / \mathrm{min})\end{array}$ & $\begin{array}{l}\text { Growth } \\
\text { Rate } \\
\left(\mathrm{cm}^{2} / \mathrm{min}\right)\end{array}$ & $\begin{array}{l}\text { SAMICS } \\
\text { Priç } \\
\left(q / M^{2}\right)\end{array}$ \\
\hline 100 & 400 & 0.20 & $\begin{array}{l}4 \\
5 \\
6 \\
8\end{array}$ & $\begin{array}{l}40 \\
50 \\
60 \\
80\end{array}$ & $\begin{array}{l}14.1 \\
12.5 \\
11.4 \\
10.1\end{array}$ \\
\hline 100 & $\begin{array}{l}400 \\
500 \\
600 \\
800\end{array}$ & 0.20 & 6 & 6 & $\begin{array}{l}11.4 \\
12.0 \\
12.6 \\
13.7\end{array}$ \\
\hline $\begin{array}{r}50 \\
100 \\
200\end{array}$ & 500 & 0.20 & 6 & 60 & $\begin{array}{l}14.8 \\
12.0 \\
10.6\end{array}$ \\
\hline
\end{tabular}


TABLE $\|$

ADD-ON AND TOTAL PRICE FOR RECRYSTALLIZED (RTR)

SILICON RIBBON - $100 \mu \mathrm{m}$ THICK

GROWTH

RATE

$100 \mathrm{~cm}^{2} / \mathrm{min}$

$150^{*} \mathrm{~cm}_{2}^{2} / \mathrm{min}$

$200^{*} \mathrm{~cm}_{2}^{2} / \mathrm{min}$

$250^{*} \mathrm{~cm}^{2} / \mathrm{min}$

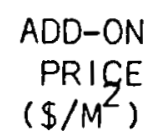

17.7

12.2

10.3

7.9

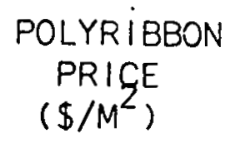

12.6

12.6

12.6

12.6
TOTAL

PRICE

$\left(\$ / M^{2}\right)$

30.3

24.3

22.9

19.5

* These growth rates could readily be achieved with multiple ribbon growth. 

PLANS:

Pinpointine the source of contamination in RTP growth will ton the number one prlority. Experiments Involving highly controlled purgad atmospheres and a variety of pre-cleaning techniques will be conducted. Settering studies will also be emphasized together with other effects to maintain diffusion lengths through completion of cell fabrication. 


\subsection{PROBLEMS}

The short diffusion lengths appearing in as-grown and gettered ribbons is a major concern. While long diffusion lengths have been obtained, this has not been on a regular basis. The extra effort necessary to solve this problem has necessarily slowed progress in other areas. 
The following New Technology items have been developed on this program:

1. Description - Polygan Scanner System

Innovator - Dr: Richard Gurtler

Progress Reports - Technical Progress Report No. 14, October 1977

Pages $-1,10,11 \mathrm{~A}$ and 11

2. Description - Hermispherical Reflertor to Improve Effective Absorption Coefficient of Liquid Sillicon

Innovator - Dr. Richard Gurtler

Progress Reports - Technical Quarterly Report No. 7, Motorola

Report 2256/9, January 1, 1978 - March 31, 1978

Pages - Appendix Pages 11 to 13

3. Description - Dendritic Growth on RTR Silicon

Imiovaluses = Di. A. Baighandi, R.J. Ellis, Dr. R.W. Gurtlor

Progress Reports - Technical Quarterly Report No. 6, Mojtorola

Report No. 2256/8, October 10, 1977 - December 31, 1977

Pages - 14-23.

4. Description - Controlled Dendrltic Growth

Innovators: Dr. A. Baghdadi and Mr. R.J. Ellis

Progress Reports - Monthly Report No. 21, August 1978,

JPL/DOE No. 954376

Page - 1

5. Description - Coated Substrates for Silicon Deposition

Innovator - Dr. R. Legge

Progress Reports - Monthly Report No. 20, July 1978,

JPL/DOE NO. 95476

Page - 20 


\section{REFERENCES}

(1) Special Report to R. Kachare, JPL.

(2) K. R. Sarma, Personal communication.

(3) Optical Spectra. October 1978, p. 28. 